\title{
Agronomic performance of soybean cultivars in an agroforestry system ${ }^{1}$
}

\author{
Flávia Werner ${ }^{2}$, Alvadi Antonio Balbinot Junior ${ }^{3}$, \\ Julio Cezar Franchini ${ }^{3}$, André Sampaio Ferreira ${ }^{2}$, Marcelo Augusto de Aguiar e Silva ${ }^{2}$
}

\section{ABSTRACT}

Combining forest and crop species into a production system may enhance its sustainability. This study aimed to evaluate the yield components, yield and grain quality of soybean cultivars, in an agroforestry system containing Eucalyptus grandis. A complete randomized block design, in a split-plot arrangement, with three replications, was used. Four soybean cultivars were allocated into the plots (BRS 359 RR, BRS 360 RR, BMX Potência RR and NA 5909 RR). The subplots consisted of five positions between the rows of E. grandis (spaced in $28 \mathrm{~m}$ - close to the trees on the east and west sides, intermediate position on the east and west sides and at the center of the row). The yield components and soybean grain yield reduce significantly the closer the plants are seeded to the rows of E. grandis. However, the oil and protein contents in soybean grains are not influenced by the position between rows, regardless of the cultivar. Among all evaluated cultivars, NA 5909 RR presents the best agronomic performance in the agroforestry system containing eucalyptus.

KEYWORDS: Glycine max L. Merrill; Eucalyptus grandis Hill ex. Maiden; grain quality.

\section{INTRODUCTION}

The increasing demand for food, fibers and agro-energy, along with production upscaling, search for practical solutions in production processes and advancement in mechanization, have transformed modern agricultural activities into simplified and standardized systems. However, this model has been considered insufficient and has shown signals of saturation, because of excessive demands for energy and natural resources, which elevate production costs and increase risks of economic failure (Reynolds et al. 2007, Balbino et al. 2011, Nair 2011, Pezarico et al. 2013).

\section{RESUMO}

Desempenho agronômico de cultivares de soja em sistema agroflorestal

O consórcio de espécies florestais e agrícolas pode contribuir para a intensificação sustentável dos sistemas de produção. Objetivouse avaliar os componentes de rendimento, a produtividade e a qualidade de grãos de cultivares de soja, em sistema agroflorestal com Eucalyptus grandis. O delineamento utilizado foi o de blocos completos casualizados, em parcelas subdivididas, com três repetições. Nas parcelas, foram alocadas quatro cultivares de soja (BRS 359 RR, BRS 360 RR, BMX Potência RR e NA 5909 RR) e, nas subparcelas, cinco posições entre os renques de $E$. grandis (espaçados em $28 \mathrm{~m}$ próximo às árvores nas posições leste e oeste, posição intermediária nos lados leste e oeste e no centro do entre renque). Os componentes de rendimento e a produtividade de grãos de soja apresentam redução acentuada quando cultivadas mais próximas dos renques de $E$. grandis, entretanto, os teores de óleo e proteína nos grãos não são alterados pela posição entre renques, independentemente da cultivar. Dentre as cultivares avaliadas, NA 5909 RR apresenta o melhor desempenho agronômico em sistema agroflorestal com eucalipto.

PALAVRAS-CHAVE: Glycine max L. Merril; Eucalyptus grandis Hill ex. Maiden; qualidade de grãos.

In this context, the only viable alternative is to use efficient production systems that take advantage of the available resources in agrosystems and, simultaneously, improve soil quality, which is the basis for all animal or vegetable production. Such systems can reduce the consumption of inputs and generate more income in a given space (Balbinot Junior et al. 2009, Paciullo et al. 2011). Integrated systems can contribute to the soybean production sustainability in different regions of Brazil, making them an option for increasing and diversifying the producer income, as well as for further improvement of no-tillage systems (Debiasi \& Franchini 2012).

1. Manuscript received in Mar./2017 and accepted for publication in Aug./2017 (http://dx.doi.org/10.1590/1983-40632016v4745937).

2. Universidade Estadual de Londrina, Centro de Ciências Agrárias, Departamento de Agronomia, Londrina, PR, Brasil.

E-mails: flawerner6@gmail.com, andresampaioferreira@gmail.com, aguiaresilva@uel.br.

3. Empresa Brasileira de Pesquisa Agropecuária (Embrapa Soja), Londrina, PR, Brasil.E-mails: alvadi.balbinot@embrapa.br, julio.franchini@embrapa.br. 
During the last decade, integrated systems combining soybean and cattle raising have significantly increased in Brazil, presenting economic and environmental advantages (Vilela et al. 2011). However, the insertion of soybean crops into agroforestry systems is still at its initial stage, given the lack of adequate technology for cultivating crops in association with trees. On one hand, rows of trees reduce the temperature spikes and wind speed in crops, minimizing evapotranspiration (Singh et al. 2012, Udawatta et al. 2014), as well as efficiently conserving soil and water. On the other hand, trees may compete for environmental natural resources such as water, light and nutrients, which, in turn, may reduce oleaginous growth and production. In general, little information has been provided regarding the variability among commercial cultivars with different genetic bases, as well as concerning their capacity to adapt to agroforestry environments (Franchini et al. 2014). Furthermore, the impacts of trees on the contents of protein and oil in soybean are still unknown.

This study aimed to evaluate the yield components, yield and grain quality of soybean cultivars in an agroforestry system with Eucalyptus grandis.

\section{MATERIAL AND METHODS}

The experiments were conducted in Londrina, Paraná state, Brazil $\left(23^{\circ} 48^{\prime} \mathrm{S}, 50^{\circ} 98^{\prime} \mathrm{W}, 500 \mathrm{~m}\right.$ a.s.1., Cfa Köpen-Geiger climate, Rhodic Eutrudox soil type, USDA), during the 2014/2015 and $2015 / 2016$ growing seasons. Formerly, analyses of the $0-20 \mathrm{~cm}$ soil layer showed the following results: organic matter $=25.5 \mathrm{~g} \mathrm{dm}^{-3} ; \mathrm{pH}\left(\mathrm{CaCl}_{2}\right)=5.5$; $\mathrm{P}($ Mehlich $)=19.2 \mathrm{mg} \mathrm{dm}^{-3} ; \mathrm{K}=0.62 \mathrm{cmol}_{\mathrm{c}} \mathrm{dm}^{-3}$; $\mathrm{Ca}=5.6 \mathrm{cmol}_{\mathrm{c}} \mathrm{dm}^{-3} ; \mathrm{Mg}=1.7 \mathrm{cmol}_{\mathrm{c}} \mathrm{dm}^{-3} ; \mathrm{CEC}$ saturation per basis $=65 \%$. The experiments were conducted in the same location for both growing seasons. The data regarding rainfall and minimum, average and maximum air temperatures, during the research period, are shown in Figure 1.

At the location of the experiment, there were nearly $250 \mathrm{E}$. grandis trees ha $\mathrm{g}^{-1}$, averaging 5 years of age, $15 \mathrm{~m}$ of height, pruned at $6 \mathrm{~m}$, arranged in simple rows allocated in level, with a $28-\mathrm{m}$ space between rows. Since the agroforestry system was implemented in 2010, the area has been grown under no-tillage, rotating soybeans, corn, wheat and black oat.
Soybean seeds were sown on November 20 (2014) and November 27 (2015). Prior to sowing, the seeds were treated with Carboxin $\left(30 \mathrm{~g}\right.$ a.i. $50 \mathrm{~kg}^{-1}$ of seeds) and Thiram (30 g a.i. $50 \mathrm{~kg}^{-1}$ of seeds) and inoculated with Bradyrhizobium elkanii, at a concentration of $5 \times 10^{9}$ colony forming units per $\mathrm{mL}$, in a $100-\mathrm{mL}$ dose per $50 \mathrm{~kg}$ of seeds. In the base fertilization, $350 \mathrm{~kg} \mathrm{ha}^{-1}$ of the formulation 0:20:20 (Embrapa 2011) were applied at the sowing furrow. Plant density and spacing were 350,000 plants $^{-1}$ and $0.5 \mathrm{~m}$, respectively. Disease, pest and weed controls were performed according to technical indications for the crop (Embrapa 2011).

The experimental design was a randomized complete block, with three replications, in a split-plot scheme. In the plot, four modern soybean cultivars of undetermined growth type were allocated. The cultivars were BRS 359 RR, BRS 360 RR, BMX Potência RR and NA 5909 RR, which contain relative maturity groups of 6.0, 6.2, 6.7 and 5.9, respectively. Between the rows of E. grandis, five soybean-
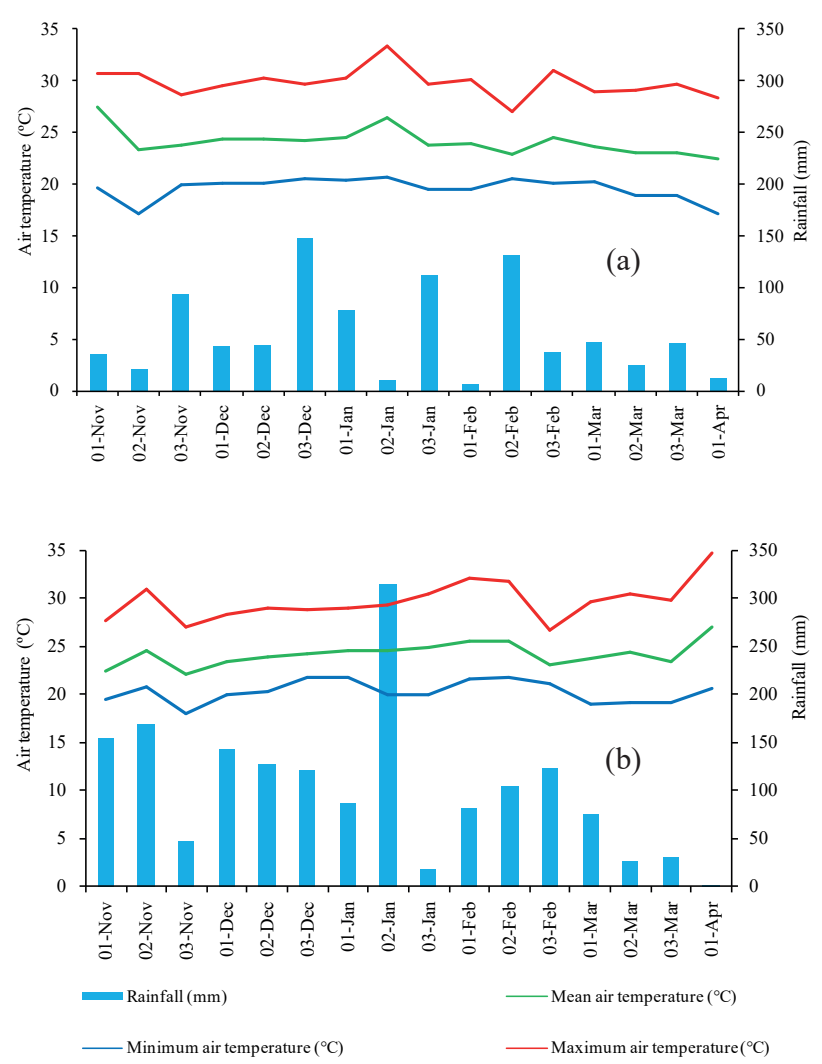

Figure 1. Rainfall (mm) and maximum, average and minimum air temperatures $\left({ }^{\circ} \mathrm{C}\right)$, during the soybean development in the 2014/2015 (a) and 2015/2016 (b) growing seasons, in Londrina, Paraná state, Brazil. 
seeding positions were considered in the subplots [close to the trees on the east and west sides $(2.0 \mathrm{~m})$, intermediate on the east and west sides and central]. The subplots were $10-\mathrm{m}$ long and $5-\mathrm{m}$ wide $\left(50.0 \mathrm{~m}^{2}\right)$. The evaluations were carried out in an area of $12 \mathrm{~m}^{2}$ ( $8.0 \mathrm{~m} \times 1.5 \mathrm{~m}$ ) per subplot (Figure 2).

Soybean yield was determined by sampling plants within the floor area of each subplot, in which the data were corrected for $13 \%$ humidity and expressed by $\mathrm{kg} \mathrm{ha}^{-1}$. Ten plants were collected sequentially in each subplot for assessment of plant height, number of pods per plant, number of grains per pod and 1,000-grain mass.

Protein and oil contents in the samples were determined by assessing intact soybeans, using the Near Infrared Spectroscopy (NIR) technique (Heil 2010). The intact and clean grains from each sample were submitted to readings in an Antaris II FT-NIR Analyzer (Thermo Fisher, EUA), containing an integrating sphere of 4-cm resolution, an average of 32 scans and background at each reading. Mathematical models, developed by the Embrapa Soja, in 2011/2012, were used for predictions of protein [180 standards, coefficient of correlation $(\mathrm{r})=0.97$, standard error of calibration $(\mathrm{RMSEC})=$ $0.64]$ and oil (170 standards, $r=0.98$, RMSEC $=$ $0.45)$.

The data were analyzed for normality and homoscedasticity by the Shapiro-Wilk and Hartley tests, respectively. The data were, subsequently, submitted to analysis of variance (Anova). Multiple comparisons of means were made by the Scott-Knott test at $\mathrm{p} \leq 0.05$. These statistical analyses were performed using the Sisvar software (Ferreira 2011).

\section{RESULTS AND DISCUSSION}

In both growing seasons, no interaction was observed between cultivars and plant positions within tree rows for yield components. In the 2014/2015 growing season, the number of pods per plant was lower for plants located near the east trees. Conversely, in the 2015/2016 growing season, highest values for this variable were found in the central location between tree rows (Table 1). Therefore, the environment had a great influence on the number of pods per plant (Kantolic \& Slafer 2007). The number of grains per pod showed no variation with position within tree rows in the 2014/2015 growing season, with expected results for the cultivars evaluated (about 2 grains pod ${ }^{-1}$ ) (Ferreira et al. 2016). In $2015 / 2016$, plants located in the central position presented a higher number of grains per pod than did the other positions, however, with no difference, if compared to plants located near the east trees.

In both growing seasons, the 1,000-grain mass reduced from the center toward the tree rows. The environment had less influence on this variable than on the number of pods per plant (Ferreira et al. 2016). Nevertheless, under severe interspecific competition, as seen here, grain filling may be limited, resulting in lower grain mass values.

The yield components (number of pods per plant and 1,000-grain mass) reduce the closer to the

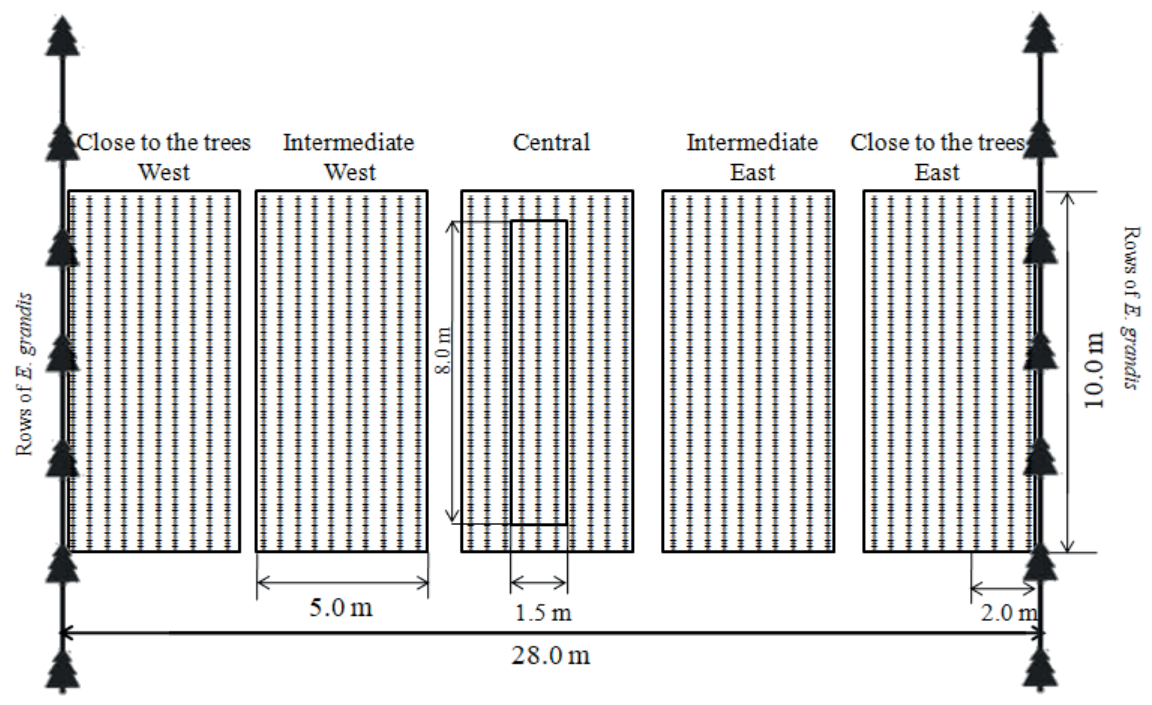

Figure 2. Positions of the soybean subplots between the rows of Eucalyptus grandis. 
tree rows the soybeans are, due to the competition for light, water and nutrients (Franchini et al. 2014). The plants situated under the tree canopy are submitted to low available luminosity, what reduces the stomatal opening and, in turn, reduces perspiration and $\mathrm{CO}_{2}$ fixation. Therefore, the ratio between internal and external $\mathrm{CO}_{2}$ concentration increased, due to the low photosynthetically active radiation (Ding \& Su 2010). With light absorption reduction, the photosynthesis photochemical phase, electron transport chain and biochemical phase when $\mathrm{CO}_{2}$ is converted into sugars - are all impaired (Mendes et al. 2013). Decreasing the photoassimilate production, the vegetative and reproduction growth are debilitated, reducing the formation of new leaves, pods and grains. Additionally, the trees may compete for water and nutrients, depriving the soybean of these fundamental resources, which are necessary for growth and formation of the yield components (Franchini et al. 2014).

There was an isolated effect of cultivars for the number of grains per pod and 1,000-grain mass in the 2014/2015 growing season (Table 2). The number of grains per pod was higher for the BRS $360 \mathrm{RR}$ and

Table 1. Number of pods per plant, grains per pod and 1,000-grain mass in different positions between the rows of Eucalyptus grandis (average of four soybean cultivars), in the 2014/2015 and 2015/2016 growing seasons.

\begin{tabular}{|c|c|c|}
\hline \multirow{2}{*}{$\begin{array}{l}\text { Position between tree rows } \\
\text { of Eucalyptus grandis }\end{array}$} & $2014 / 2015$ & $2015 / 2016$ \\
\hline & \multicolumn{2}{|c|}{ Number of pods plant ${ }^{-1}$} \\
\hline Close to the trees on the east & $25.9 \mathrm{~A}^{1}$ & $15.0 \mathrm{~B}$ \\
\hline Intermediate on the east & $31.1 \mathrm{~A}$ & $18.0 \mathrm{~B}$ \\
\hline Central & $28.4 \mathrm{~A}$ & $24.9 \mathrm{~A}$ \\
\hline Intermediate on the west & $26.3 \mathrm{~A}$ & $18.8 \mathrm{~B}$ \\
\hline Close to the trees on the west & $15.1 \mathrm{~B}$ & $16.1 \mathrm{~B}$ \\
\hline \multirow[t]{2}{*}{$\mathrm{CV}(\%)$} & 24.2 & 24.5 \\
\hline & \multicolumn{2}{|c|}{ Number of grains pod ${ }^{-1}$} \\
\hline Close to the trees on the east & $2.33 \mathrm{~A}$ & $1.52 \mathrm{~B}$ \\
\hline Intermediate on the east & $2.21 \mathrm{~A}$ & $1.63 \mathrm{~B}$ \\
\hline Central & $2.17 \mathrm{~A}$ & $1.74 \mathrm{~A}$ \\
\hline Intermediate on the west & $2.14 \mathrm{~A}$ & $1.59 \mathrm{~B}$ \\
\hline Close to the trees on the west & $2.14 \mathrm{~A}$ & $1.70 \mathrm{~A}$ \\
\hline \multirow[t]{2}{*}{ CV (\%) } & 10.00 & 7.60 \\
\hline & \multicolumn{2}{|c|}{1,000 -grain mass $(\mathrm{g})$} \\
\hline Close to the trees on the east & $131 \mathrm{~B}$ & $76 \mathrm{~B}$ \\
\hline Intermediate on the east & $132 \mathrm{~B}$ & $83 \mathrm{~B}$ \\
\hline Central & $141 \mathrm{~A}$ & $100 \mathrm{~A}$ \\
\hline Intermediate on the west & $138 \mathrm{~A}$ & $111 \mathrm{~A}$ \\
\hline Close to the trees on the west & $127 \mathrm{~B}$ & $86 \mathrm{~B}$ \\
\hline $\mathrm{CV}(\%)$ & 6.2 & 16.3 \\
\hline
\end{tabular}

BMX Potência RR cultivars (Table 2). The grain mass was lower for the BMX Potência RR cultivar. In 2015/2016, no difference was found between the cultivars for the yield components evaluated.

The interaction between the studied factors occurred for yield in both growing seasons. In the 2014/2015 season, for all cultivars evaluated, the positions closest to the trees were the least productive ones (Table 3). This effect seems to be due to the competition for resources imposed by the trees. At intermediate positions (west and central), BRS 359 RR and BRS 360 RR presented the lowest yield results, while NA 5909 RR presented the highest yield results, showing the better adaptation of the latter to this environmental condition. Thus, NA 5909 RR may reach a satisfactory yield in this type of system, when compared to the other cultivars. These results show the need for a plant-breeding program to develop new soybean cultivars adapted to growth under sub-forest conditions.

In the 2015/2016 growing season, the positions closest to the trees, for all cultivars, also provided the lowest yield (Table 3 ). These results once again suggest that competition with eucalyptus impairs the soybean development and, consequently, limits yield, even under atmospheric conditions favorable

Table 2. Number of pods per plant, grains per pod and 1,000-grain mass for soybean cultivars (average of five positions between the rows of Eucalyptus grandis), in the 2014/2015 and 2015/2016 growing seasons.

\begin{tabular}{lcc}
\hline \multirow{2}{*}{ Cultivar } & 2014/2015 & $2015 / 2016$ \\
\cline { 2 - 3 } & \multicolumn{2}{c}{ Number of pods plant ${ }^{-1}$} \\
\hline BRS 359 RR & $21.8 \mathrm{~A}^{1}$ & $16.5 \mathrm{~A}$ \\
BRS 360 RR & $26.8 \mathrm{~A}$ & $18.2 \mathrm{~A}$ \\
BMX Potência RR & $25.5 \mathrm{~A}$ & $20.3 \mathrm{~A}$ \\
NA 5909 RR & $27.3 \mathrm{~A}$ & $19.1 \mathrm{~A}$ \\
\hline CV (\%) & 21.6 & 24.4 \\
\hline & Number of grains pod ${ }^{-1}$ \\
\hline BRS 359 RR & $2.14 \mathrm{~B}$ & $1.68 \mathrm{~A}$ \\
BRS 360 RR & $2.28 \mathrm{~A}$ & $1.72 \mathrm{~A}$ \\
BMX Potência RR & $2.32 \mathrm{~A}$ & $1.67 \mathrm{~A}$ \\
NA 5909 RR & $2.05 \mathrm{~B}$ & $1.71 \mathrm{~A}$ \\
\hline CV (\%) & 7.50 & 17.30 \\
\hline & 1,000 -grain mass (g) \\
\hline BRS 359 RR & $147 \mathrm{~A}$ & $100 \mathrm{~A}$ \\
BRS 360 RR & $134 \mathrm{~A}$ & $86 \mathrm{~A}$ \\
BMX Potência RR & $111 \mathrm{~B}$ & $84 \mathrm{~A}$ \\
NA 5909 RR & $143 \mathrm{~A}$ & $95 \mathrm{~A}$ \\
\hline CV (\%) & 8.4 & 21.1 \\
\hline${ }^{1}$ Means followed by the same capital letter in the column do not differ by the \\
Scott-Knott test (p $\leq 0.05)$. & &
\end{tabular}


Table 3. Soybean grain yield $\left(\mathrm{kg} \mathrm{ha}^{-1}\right)$ for cultivars and positions between tree rows of Eucalyptus grandis, in the 2014/2015 and 2015/2016 growing seasons.

\begin{tabular}{|c|c|c|c|c|c|}
\hline \multirow{3}{*}{ Cultivar } & \multicolumn{5}{|c|}{ Position between tree rows of Eucalyptus grandis } \\
\hline & Close west & Intermediate west & Central & Intermediate east & Close east \\
\hline & \multicolumn{5}{|c|}{$2014 / 2015$} \\
\hline BRS 359 RR & $2,561 \mathrm{Aa}^{1}$ & $2,864 \mathrm{Ba}$ & $2,583 \mathrm{Ba}$ & $2,948 \mathrm{Aa}$ & $1,324 \mathrm{Ab}$ \\
\hline BRS 360 RR & $1,958 \mathrm{Ab}$ & $2,846 \mathrm{Ba}$ & $2,923 \mathrm{Ba}$ & $2,991 \mathrm{Aa}$ & $1,422 \mathrm{Ab}$ \\
\hline BMX Potência RR & $1,732 \mathrm{Ab}$ & $2,981 \mathrm{Ba}$ & $3,416 \mathrm{Aa}$ & $2,854 \mathrm{Aa}$ & $1,114 \mathrm{Ac}$ \\
\hline NA 5909 RR & $2,152 \mathrm{Ab}$ & $3,770 \mathrm{Aa}$ & $3,826 \mathrm{Aa}$ & $3,455 \mathrm{Aa}$ & $1,555 \mathrm{Ac}$ \\
\hline CV $1(\%)$ & \multicolumn{5}{|c|}{21.4} \\
\hline \multirow[t]{2}{*}{ CV $2(\%)$} & \multicolumn{5}{|c|}{12.8} \\
\hline & \multicolumn{5}{|c|}{$2015 / 2016$} \\
\hline BRS 359 RR & $697 \mathrm{Ac}$ & $872 \mathrm{Bc}$ & $1,701 \mathrm{Aa}$ & $1,334 \mathrm{Bb}$ & $987 \mathrm{Ac}$ \\
\hline BRS 360 RR & $621 \mathrm{Ab}$ & $1,490 \mathrm{Aa}$ & $1,398 \mathrm{Aa}$ & $1,338 \mathrm{Ba}$ & $678 \mathrm{Ab}$ \\
\hline BMX Potência RR & $318 \mathrm{Ac}$ & $1,128 \mathrm{Ba}$ & $737 \mathrm{Bb}$ & $662 \mathrm{Cb}$ & $740 \mathrm{Ab}$ \\
\hline NA 5909 RR & $467 \mathrm{Ad}$ & $1,353 \mathrm{Ab}$ & $1,024 \mathrm{Bc}$ & $1,710 \mathrm{Aa}$ & $642 \mathrm{Ad}$ \\
\hline CV $1(\%)$ & \multicolumn{5}{|c|}{20.9} \\
\hline CV $2(\%)$ & \multicolumn{5}{|c|}{21.0} \\
\hline
\end{tabular}

to oleaginous plants (Figure 1). At the intermediate west position, BRS 360 RR and NA 5909 RR reached the highest yield. Yet in the central position, BRS 360 RR and BRS 359 RR reached the best results, when compared to the other cultivars. For the intermediate east position, the only significantly different cultivar was NA 5909 RR, with the highest yield.

Franchini et al. (2014) also observed a high negative impact of eucalyptus tree rows on soybean yield. However, the authors did not study which were the most impacting environmental factors (light, water or nutrients) on the interspecific competition between soybean and eucalyptus.

Whereas rainfall was adequate in both growing seasons for soybean (Figure 1), as well as soil fertility and fertilization were adequate for cropping (Embrapa 2011), the competition for light, exerted by the eucalyptus, seems to be the main factor limiting the achievement of the production potential of soybean cultivars. The soybean plant fixates carbon through a C3 cycle, presenting a low luminous efficiency and a high light compensation point. Therefore, relatively high quantities of light are required to produce photoassimilates (Casaroli et al. 2007). When luminosity is lower than the luminous compensation point, the oxidation of carbon by cellular respiration overcomes the carbon fixation by photosynthesis, reducing the net photosynthesis rate and, consequently, the dry matter production. On the other hand, the soybean plant is relatively tolerant to adverse atmospheric conditions, especially during its vegetative period. It presents a good recovery capacity, though high yield is only possible if ideal hydric, light and temperature conditions are met (Reynolds et al. 2007).

Yield in the 2015/2016 growing season was very low, because of the excess of rain during the grain-filling period. Additionally, the protein content was high, when compared to normal results obtained in cultivation (Ferreira et al. 2016). The protein content presented a significant effect for the cultivars, indicating similarity between BMX Potência RR and BRS 359 RR, in the 2014/2015 growing season. In 2015/2016, however, no significant effect of cultivar was observed (Table 4).

Table 4. Oil and protein contents in soybean grains of four cultivars (average of five positions between tree rows of Eucalyptus grandis), in the 2014/2015 and 2015/2016 growing seasons.

\begin{tabular}{lcc}
\hline \multirow{2}{*}{ Cultivar } & $2014 / 2015$ & $2015 / 2016$ \\
\cline { 2 - 3 } & \multicolumn{2}{c}{ Oil (\%) } \\
\hline BRS 359 RR & $21.6 \mathrm{~A}^{1}$ & $19.1 \mathrm{~A}$ \\
BRS 360 RR & $21.9 \mathrm{~A}$ & $18.8 \mathrm{~A}$ \\
BMX Potência RR & $20.9 \mathrm{~A}$ & $18.4 \mathrm{~A}$ \\
NA 5909 RR & $22.3 \mathrm{~A}$ & $18.9 \mathrm{~A}$ \\
\hline CV (\%) & 3.8 & 4.5 \\
\hline & \multicolumn{2}{c}{ Protein (\%) } \\
\hline BRS 359 RR & $37.1 \mathrm{~A}$ & $41.5 \mathrm{~A}$ \\
BRS 360 RR & $36.2 \mathrm{~B}$ & $41.4 \mathrm{~A}$ \\
BMX Potência RR & $37.3 \mathrm{~A}$ & $42.4 \mathrm{~A}$ \\
NA 5909 RR & $35.5 \mathrm{~B}$ & $41.1 \mathrm{~A}$ \\
\hline CV(\%) & 2.6 & 2.8 \\
\hline
\end{tabular}

${ }^{1}$ Means followed by the same capital letter in the columns do not differ by the Scott-Knott test $(\mathrm{p} \leq 0.05)$. 
Table 5. Oil and protein contents in soybean grains of five positions between tree rows of Eucalyptus grandis (average of four soybean cultivars), in the 2014/2015 and 2015/2016 growing seasons.

\begin{tabular}{lcc}
\hline \multirow{2}{*}{$\begin{array}{c}\text { Position between tree rows } \\
\text { of Eucalyptus grandis }\end{array}$} & \multicolumn{2}{c}{ Oil (\%) } \\
\cline { 2 - 3 } Close to the trees on the east & $21.5 \mathrm{~A}^{1}$ & $18.6 \mathrm{~A}$ \\
Intermediate on the east & $21.6 \mathrm{~A}$ & $18.7 \mathrm{~A}$ \\
Central & $21.5 \mathrm{~A}$ & $19.2 \mathrm{~A}$ \\
Intermediate on the west & $21.6 \mathrm{~A}$ & $18.8 \mathrm{~A}$ \\
Close to the trees on the west & $21.9 \mathrm{~A}$ & $18.8 \mathrm{~A}$ \\
\hline CV $(\%)$ & 4.2 & 9.8 \\
\hline & \multicolumn{2}{c}{ Protein (\%) } \\
\hline Close to the trees on the east & $36.7 \mathrm{~A}$ & $41.7 \mathrm{~A}$ \\
Intermediate on the east & $36.6 \mathrm{~A}$ & $41.4 \mathrm{~A}$ \\
Central & $36.6 \mathrm{~A}$ & $41.4 \mathrm{~A}$ \\
Intermediate on the west & $36.6 \mathrm{~A}$ & $41.7 \mathrm{~A}$ \\
Close to the trees on the west & $36.2 \mathrm{~A}$ & $41.7 \mathrm{~A}$ \\
\hline CV $(\%)$ & 2.2 & 5.6 \\
\hline${ }^{1}$ Means followed by the same capital letter in the columns do not differ by the \\
Scott-Knott test $(\mathrm{p} \leq 0.05)$.
\end{tabular}

In contrast, the oil content in the grains was not affected by the experimental factors, nor by the interaction between them (Tables 4 and 5). This outcome denotes that the oil content may be less influenced by environmental factors (Dardanelli et al. 2006, Gao et al. 2009). The protein and oil contents in soybeans are genetically determined, but may be influenced by the environment during the grain-filling period (Ávila et al. 2007). Information of this nature may contribute to elucidate the causes of different behaviors among cultivars, when the grains are exposed to stressful situations (Minuzzi et al. 2009). Therefore, in this production environment, which is restrictive to their metabolism, the plants may prioritize protein synthesis over carbohydrate and oil synthesis in grains.

\section{CONCLUSIONS}

1. The yield components and soybean yield reduce significantly the closer the plants are seeded to the tree rows of Eucalyptus grandis. However, the oil and protein contents in soybean grains are not influence by the tree interference, regardless of the cultivar;

2. Among all cultivars evaluated, NA 5909 RR presents the best agronomic performance in the agroforestry system with eucalyptus.

\section{REFERENCES}

ÁVILA, M. R. et al. Componentes do rendimento, teores de isoflavonas, proteínas, óleo e qualidade de sementes de soja. Revista Brasileira de Sementes, v. 29, n. 3, p. 111127, 2007.

BALBINO, L. C. et al. Evolução tecnológica e arranjos produtivos de sistemas de integração lavoura-pecuáriafloresta no Brasil. Pesquisa Agropecuária Brasileira, v. 46, n. 10, p. 1-12, 2011.

BALBINOT JUNIOR, A. A. et al. Integração lavourapecuária: intensificação de uso de áreas agrícolas. Ciência Rural, v. 39, n. 6, p. 1925-1933, 2009.

CASAROLI, D. et al. Radiação solar e aspectos fisiológicos na cultura de soja: uma revisão. Revista da FZVA, v. 14, n. 2, p. 102-120, 2007.

DARDANELLI, J. L. et al. Soybean maturity groups, environments, and their interaction define megaenvironments for seed composition in Argentina. Crop Science, v. 46, n. 5, p. 1939-1947, 2006.

DEBIASI, H.; FRANCHINI, J. C. Atributos físicos do solo e produtividade da soja em sistema de integração lavoura-pecuária com braquiária e soja. Ciência Rural, v. 42, n. 7, p. 1180-1186, 2012.

DING, S.; SU, P. Effects of tree shading on maize crop within a Poplar-maize compound system in Hexi Corridor oasis, northwestern China. Agroforestry Systems, v. 80, n. 1, p. 117-129, 2010.

EMPRESA BRASILEIRA DE PESQUISA AGROPECUÁRIA(Embrapa). Tecnologias de produção de soja: região central do Brasil 2012 e 2013. 21. ed. Londrina: Embrapa Soja, 2011.

FERREIRA, A. S. et al. Plant density and mineral nitrogen fertilization influencing yield, yield components and concentration of oil and protein in soybean grains. Bragantia, v. 75, n. 3, p. 362-370, 2016.

FERREIRA, D. F. Sisvar: a computer statistic analysis system. Ciência e Agrotecnologia, v. 35, n. 6, p. 10391042, 2011.

FRANCHINI, J. C. et al. Yield of soybean, pasture and wood in integrated crop-livestock-forest system in northwestern Paraná state, Brazil. Revista Ciência Agronômica, v. 45, n. 5, p. 999-1005, 2014.

GAO, J. et al. Agronomic management system and precipitation effects on soybean oil and fatty acid profiles. Crop Science, v. 49, n. 1, p. 1049-1057, 2009.

HEIL, C. Rapid, multi-component analysis of soybeans by FT-NIR spectroscopy. Madison: Thermo Fisher Scientific, 2010. 
KANTOLIC, A. G.; SLAFER, G. A. Development and seed number in indeterminate soybean as affected by timing and duration of exposure to long photoperiods after flowering. Annals of Botany, v. 99, n. 5, p. 925-933, 2007.

MENDES, M. M. S. et al. Desenvolvimento do milho sob influência de árvores de pau-branco em sistema agrossilvipastoril. Pesquisa Agropecuária Brasileira, v. 48, n. 10, p. 1342-1350, 2013.

MINUZZI, A. et al. Rendimento de teores de óleo e proteínas de quatro cultivares de soja, produzidas em dois locais no Estado do Mato Grosso do Sul. Ciência e Agrotecnologia, v. 33, n. 4, p. 80-93, 2009.

NAIR, P. K. R. Agroforestry systems and environmental quality: introduction. Journal of Environmental Quality, v. 40, n. 3, p. 784-790, 2011.

PACIULLO, D. S. C. et al. Características produtivas e nutricionais do pasto em sistema agrossilvipastoril, conforme a distância das árvores. Pesquisa Agropecuária Brasileira, v. 46, n. 10, p. 1176-1183, 2011.
PEZARICO, C. R. et al. Indicadores de qualidade do solo em sistemas agroflorestais. Revista de Ciências Agrárias, v. 56, n. 1, p. 40-47, 2013.

REYNOLDS, P. E. et al. Effects of tree competition on corn and soybean photosynthesis, growth, and yield in a temperate tree-based agroforestry intercropping system in southern Ontario, Canada. Ecological Engineering, v. 29, n. 4, p. 362-371, 2007.

SINGH, A. K. et al. Dynamics of tree-crop interface in relation to their influence on microclimatic changes: a review. HortFlora Research Spectrum, v. 1, n. 3, p. 193198, 2012.

UDAWATTA, R. P. et al. Temporal and spatial differences in crop yields of a mature silver maple alley cropping system. Agronomy Journal, v. 106, n. 2, p. 407-415, 2014.

VILELA, L. et al. Sistemas de integração lavoura-pecuária na região do Cerrado. Pesquisa Agropecuária Brasileira, v. 46, n. 10, p. 1127-1138, 2011. 